\title{
Local Fisheries Co-management: A Review of International Experiences and Their Implications for Salmon Management in British Columbia
}

\author{
Evelyn W. Pinkerton \\ School of Community and Regional Planning, University of British Columbia, 6333 Memorial Road, Vancouver, BC V6T 1Z2, Canada
}

Pinkerton, E.W. 1994. Local fisheries co-management: a review of international experiences and their implications for salmon management in British Columbia. Can. J. Fish. Aquat. Sci. 51:2363-2378.

\begin{abstract}
The theory and practice of community-based self-management and government-community co-management is examined in terms of the potential of these management systems to address some of the major biological, economic, and political problems of the salmon fishery of British Columbia, Canada. Particular attention is given to government-multiparty arrangements that integrate the concerns of multiple interests, while recognizing the special rights of aboriginal communities. Elements identified as key to the success of various arrangements include: (1) logistical arrangements, such as clear boundaries, membership criteria, interception agreements, and management-unit sizes appropriate to the abundance of natural and human resources; (2) cost-sharing arrangements, such as local cost recovery and local volunteerism; (3) power-sharing arrangements through checks and balances between local multiparty boards, a provincial board, and the Department of Fisheries and Oceans. The processes engendering social learning, through which government and local bodies could move toward such regimes, are discussed through a review of relevant literature on interorganizational conflict resolution, public policy, and organizational learning. Many of the elements of success of both arrangements and processes are likely to apply to a broad range of fisheries co-management situations.
\end{abstract}

On examine en principe et en pratique l'autogestion par des communautés et la cogestion assurée par le gouvernement et les communautés, au regard du potentiel qu'ont ces modes de gestion de régler certains grands problèmes biologiques, économiques et politiques qui sont associés à la pêche au saumon en Colombie-Britannique. On accorde une attention particulière aux ententes entre gouvernements et des intérêts multiples, ententes qui assurent l'intégration des préoccupations de ces derniers et qui font place aux droits particuliers des communautés autochtones. Voici quelques-uns des éléments jugés essentiels au succès des différentes ententes : (1) des ententes sur des aspects logistiques comme la délimitation de frontières nettes, des critères d'appartenance, des ententes sur les droits d'interception et la grandeur des unités de gestion qu'on juge être appropriées à l'abondance des ressources naturelles et humaines; (2) des ententes à partage de coûts, par exemple, où il est prévu une récupération des coûts au niveau local et qui font place au bénévolat; (3) des ententes de partage des pouvoirs qui incorporent des éléments d'équilibre des pouvoirs entre les commissions locales multilatérales, une commission provinciale et le ministère des Pêches et des Océans. On se penche sur les processus à l'origine d'un apprentissage social, et qui pourraient permettre au gouvernement et aux organismes locaux de faire la transition vers de tels régimes, en examinant des documents appropriés sur la résolution des conflits entre organisations, sur les politiques gouvernementales ainsi que sur l'apprentissage organisationnel. Bon nombre des éléments qui ont conduit au succès de pareilles ententes et processus devraient pouvoir s'appliquer à toute une série de situations où il est question de cogestion des pêches.

Received November 15, 1993

Accepted May 30, 1994

Reçu le 15 novembre 1993 (J12159)

Accepté le 30 mai 1994

B

ritish Columbia's salmon fisheries face a number of biological, economic, and political problems for which no immediate solutions are apparent under current arrangements. Some aspects of these problems, on the one hand, seem universal and unavoidable, and would look remarkably familiar to scholars and managers who have worked with fisheries around the world. On the other hand, a growing literature on local management systems on every continent suggests that solutions to other aspects of these problems are very old, and have been reinvented independently by both dispersed pre-industrial societies and by encapsulated societies within modern nation states. This literature appears in biology (Johannes 1978, 1981), human ecology (Berkes 1981), cultural ecology (Acheson 1975;
McCay and Acheson 1987; Pinkerton 1988; McGoodwin 1990; Albrecht 1990; Dyer and McGoodwin 1994), sociology (Jentoft and Kristoffersen 1989), economics (Bromley 1989), geography (Klee 1980, Ruddle and Akimichi 1984), history (McEvoy 1986), and political science (Ostrom 1990). Through greater interdisciplinary communication, the answers these local systems appear to offer are becoming better known, catalogued, and integrated into a general theory of self-management and co-management (Pinkerton 1989, 1991, 1992, 1994a, 1994b; Berkes at al. 1991; Smith 1994).

This discussion reviews a few key examples from the large literature on self-management, the much smaller literature on government-community co-management, and the sparse literature on multiparty co-management, as preparation 
for considering what implications these systems might have for salmon management in British Columbia. Because these institutions of power sharing have biological, economic, and political implications, it is helpful to first revisit these aspects of key problems facing today's salmon managers and fishers in British Columbia. We may then consider how alternative systems might ameliorate these problems.

\section{Biological Problems}

Salmon habitat loss continues to occur through water diversion, dam construction, mining, industrial pollution, real estate development, inadequate regulation of logging practices and agricultural runoff, and uncoordinated landuse planning relative to watersheds as a whole. Many of these potentially habitat-destroying activities will become more intense as population increases.

Each Pacific salmon species may be subdivided into stocks, generally considered separate interbreeding populations, each adapted to the specific environmental conditions of its natal stream (Nehlsen et al. 1991). The loss of biodiversity both through the extinction of stocks and the steady erosion of smaller stocks has particularly alarmed scientists and residents of communities formerly dependent on them. Even though aggregate salmon harvests and aggregate escapements have increased in the last decade, these are based on fewer and fewer stocks, mostly sockeye (Oncorhynchus nerka) and pink salmon (O. gorbuscha) stocks and often enhanced ones (Northcote and Atagi 1994). For example, $90 \%$ of the sockeye biomass comes from fewer than $10 \%$ of sockeye stocks. The other $90 \%$ receive relatively little management attention $(K$. Hyatt, Department of Fisheries and Oceans, Pacific Biological Station, Nanaimo, BC V9R 5K6, personal communication) One publication on South Coast stocks predicts that $35 \%$ of current stocks will be lost over the next $40 \mathrm{yr}$ if harvest patterns remain unchanged (DFO 1988). Riddell (1993) notes that one third of the salmon populations known since the $1950 \mathrm{~s}$ in the Strait of Georgia have been lost or have decreased to such low numbers that spawners are not consistently monitored. Many attempts to reintroduce salmon into areas where stocks have become extinct have failed, and it is not yet understood why successes occur in other cases (Withler 1982).

Dependence on fewer stocks is risky for many reasons (Walters 1988). Global warming and increased pollution, for example, could mean that stocks that are abundant now may disappear in the future, e.g., some Fraser River sockeye stocks, which are at the southern limit of their range (Henderson et al. 1992; Gilhousen 1990; Levy 1992; Groot et al. 1992). Conserving more stocks increases the chances that a number of productive ones will survive future changes and that annual cyclic variability in abundance will not occur in all stocks simultaneously.

One reason more stock-specific management is difficult to achieve is that the data gathering and analysis of the productivity of individual stocks, which provide the most critical information for managing salmon, are inadequate or insufficiently tied to aggregate management goals in most cases (B. Riddell, Pacific Biological Station, Department of Fisheries and Oceans, Nanaimo, BC V9R 5K6, personal communication). In many areas, stock-specific management is also hampered by the lack of in-season data on the timing and relative abundance of different stocks, and the fact that escapement targets can be "little more than educated guesses" without data on habitat status (DFO 1991). While biologists in the Department of Fisheries and Oceans (DFO) management system understand that there will never be enough resources to document all the stocks, many feel that far too many important and irreversible losses are being tolerated.

DFO is the centralized federal agency whose mandate is to collect and analyse data, administer licences, regulate harvest and habitat protection, and negotiate international agreements relating to salmon management. Important experiments by DFO have already suggested some promising directions for improvement, e.g., a planning framework for documenting salmon stock status in British Columbia, for generating options for improved management, and for piloting management innovations (DFO 1988, 1991, 1993a). This effort has been hampered so far by limited resources, and limited process development. DFO has also incorporated university-based research in a 15-yr adaptive management experiment to identify optimum escapement for sockeye in Rivers Inlet. Because the initial experiment did not produce clear results, the scientists compromised with local fishers, who supported a continued experiment involving harvest restraints only during abundant years (Walters et al. 1993).

Following these hopeful directions and other DFO discussions (Greer 1993), this discussion will review cases where local involvement in data collection, analysis, and monitoring of stocks and/or habitat is more extensive, long term, or institutionalized, and has already made significant contributions to the resolution of the types of biological problems described above.

\section{Economic Problems.}

Many B.C. fishers are no better off today than they were $10 \mathrm{yr}$ ago, despite overall increased salmon abundance in British Columbia. As DFO brings in tighter regulations (shorter fishing times and more restricted areas) to protect weaker stocks, or to comply with the Pacific Salmon Treaty, fishing opportunities become shorter and shorter. As a result of this and other factors, fishers continue to invest in bigger and faster boats and more efficient gear to travel quickly to distant openings and to take full advantage of short openings. Fuel, vessel, and gear costs rise, even if salmon prices do not.

Increasing competition among salmon-producing nations for salmon markets is already exerting downward pressure on prices. For example, increased Norwegian and Chilean production of farmed salmon affects the top end of the market (Knapp 1992). At the middle and bottom end, JapaneseRussian joint ventures in production, processing, and marketing of sockeye, chum ( $O$. keta), and pink salmon suggests that another cycle of price competition is likely to occur in the future (Kravanja 1992, Akaha 1993). Governmental management costs also continue to rise (Pearse 1982; F.E.A. Wood, Department of Fisheries and Oceans, 555 West Hastings, Vancouver, BC V6B 5G3, personal communication) while governmental budgets shrink.

In other words, the basic economic conditions of fishing continue to cut deeply into the benefits fishers and fishingdependent communities might otherwise enjoy from the resource.

Examples presented in this discussion will suggest that both the cost of management and the cost of fishing could be lowered through a greater localization of management and greater participation of local communities or organizations in management. 


\section{Political Problems}

Three types of political conflict have plagued the salmon fishery. The first is the longstanding demand from those involved in all sectors of the fishery to be far more involved in decisions that affect them. The Minister of Fisheries has broad discretionary and policy-making powers under the Fisheries Act. Although there are advisory processes at various levels, the sharing of power, data, and initiative in these is limited: agendas may be set elsewhere and recommendations may be ignored.

In most cases, fishers have little confidence that future ministerial policy will take their management concerns and their investments into account. Nor can they predict what basic values and goals will guide this policy. For example, fleet rationalization programs proposed or brought in by government over the last two decades have proved highly controversial, and have been seen as deliberately or inadvertantly dispossessing a particular group or sector without achieving the stated goals of the program (Pearse 1972; Hayward 1981; Marchak et al. 1987; Cruickshank 1991).

Exceptions to this pattern illustrate a more hopeful process for policy making, although they are rare, piecemeal, and not institutionalized. When the major commercial fishers' organization, the Commercial Fishing Industry Council, reached a coastwide agreement on salmon allocation among commercial gear sectors, the agreement was adopted by DFO as a working policy, at least for the moment (Brown 1993). DFO has begun to pilot more extensive consultative processes in key local areas as part of considering more stock specific management options (DFO 1991, 1993a; Walters et al. 1993). A key change in the latter type of process is an emphasis on stock management as opposed to fleet management, and an effort to involve fishers in in-depth discussions concerning long-term impacts of various fishing patterns on stocks. These beginnings are often attempts to transform regional advisory boards which can be narrow and nonaccountable lobbies for the status quo (Taylor 1993), to bodies more knowledgeable, participatory, and able to take a long-term view of trade-offs in management options. The long-range goal would be for all parties to be accountable to a management plan that they have agreed to implement. In the present situation, however, DFO may still unilaterally change the plan over the objections of all but the most powerful party.

The second type of conflict, namely between the longestablished commercial fishery and the growing sport fishery, has intensified in recent years. Under the current policy framework, these two sectors tend to lobby Ottawa for the enlargement of their own access and the curtailment of the others' access, rather than working together to improve the resource or the management system. In the last few years, the commercial and recreational sectors have sometimes made common cause against allocations to aboriginal peoples, called "First Nations" in Canada.

The third type of conflict results from the Supreme Court of Canada's Sparrow decision and other recent cases affirming the rights of First Nations to a priority allocation of fish, as based in section 35 of the Constitution Act of 1982. In the context of this court decision, a major confrontation in Quebec between an aboriginal group and government (the "Oka crisis"), new public opinion polls, and constitutional negotiations, Ottawa adopted a 7-yr Aboriginal Fishing Strategy (AFS) in June 1992. One element of the strategy is to develop local co-management between Ottawa and First Nations (DFO 1993b).

First Nations are place-oriented peoples whose rights to fish are linked to continuous occupation and use of traditional local territories; these areas are usually within natural boundaries such as watershed ecosystems. Therefore, new co-management agreements developed between Ottawa and individual First Nations will involve a search for new local salmon management regimes to supplement and complement the work of province-wide regimes.

What are the implications of this for nonaboriginal commercial and sport fisheries? What opportunities exist for the peaceful coexistence of commercial and sport fisheries with expanded aboriginal fisheries? Could some degree of reorientation of the salmon fishery around local areas address the longstanding biological and economic problems of the fishery, as well as the new and old political conflicts?

This paper contributes to a more general discussion of the concept of fisheries co-management by reviewing international experiences with fisheries self-management and co-management. Particular attention is paid to multiparty examples, because the question of how First Nations can work together with existing commercial and recreational fisheries is a major concern.

Innovative answers to this question now appear possible because of new research in the social sciences regarding local institutions that can protect both ecosystems and the common property access privileges and/or rights of established fishers. These local institutions perform varying degrees of self-management and management in cooperation with government. In addition, this research calls into question the wisdom of government's conventional role as a manager who involves interested parties in a merely advisory capacity. Therefore, this paper also briefly reviews new models through which watershed-based groups build a collaborative process and/or public managers stimulate policy discussion among diverse parties by organizing and supporting a "social learning" process (Reich 1988; Dale 1989). In such an exercise, public values about a public resource can be refocused in the context of problems and dilemmas that must be faced. All of these approaches taken together form part of the answer to the problems of today's salmon management.

This paper first briefly considers the theory behind an alternative approach to fisheries management. The theory is then illustrated through international examples of communitybased self-management by single groups, joint communitygovernment management, or co-management between government agencies and single groups and joint communitygovernment management in which multiple parties and their communities are involved. The discussion of these examples is then used to identify factors in the successful development of local co-management regimes. What does it take to have a successful institutional arrangement? Finally, the constructive role that collaborators and government can play in this process is considered.

\section{Institutional Solutions to the Management of Common Pool Resources: A Brief Theoretical Overview}

In parts of Europe, a privileged gentry still exercises private ownership and control of salmon streams (Netboy 1968, 1973; McCay 1989). In contrast, most North Americans of 
European origin chose to manage salmon as a public and not a private good. How the public good is defined and managed is an issue of public policy. The definition of the public good has been heavily influenced by the bioeconomic paradigm sometimes described as "the tragedy of the commons," after the discussion by Hardin (1968). This paradigm asserts that common pool' resources, such as fish, will inevitably be destroyed by the users unless they are either privatized or very tightly regulated by the state. The privatization route has been largely rejected as unpalatable to North Americans, at least for salmon, and is, therefore, not discussed here. ${ }^{2}$ Scrupulous state regulation has been seen as the way to protect a resource which is theoretically owned by all Canadians.

As noted above, state regulation alone has not solved important biological, economic, and political problems. Some of these problems have been solved or greatly ameliorated, however, by community-based forms of management, often working in tandem with state regulation. Hardin and early common pool theorists did not consider these forms of collective management viable. However, communitybased management regimes display a common pattern, and are based on some of the same fundamental understandings as that of the bioeconomic model about what causes problems in the management of common pool resources. However, the "solution" is quite different.

Institutional economists and political theorists express this understanding in terms of two characteristics of a common pool resource such as fish: nonexcludability and subtractability (Feeny et al. 1990). A brief exploration of these two concepts will help explain how community-based regimes work.

(1) Nonexcludability. The physical nature of the resource (dispersed over hundreds of miles, present at unpredictable times, highly mobile, often invisible) means that limiting access to it is costly and in some cases impossible for gov-

\footnotetext{
${ }^{1}$ The term "common pool" is used to distinguish those natural resources such as fish, wildlife, water, forests, rangelands, which by their very physical nature are difficult to manage under a simple regime such as private property. This is true partly because of the mobility, scale, or opportunities for secret use of the resource. The term "common pool" is used to distinguish the physical nature of the resource as opposed to the political regime or system of property rights through which it is managed. Common pool resources may be managed under at least four different types of political regimes or systems of property rights: open access (unregulated), private, state, community based, or combinations of these. The term "common property" is not used here, to avoid the possible confusion between the physical nature of common pool resources and the regume under which they are managed (Ciriacy-Wanthrup and Bishop 1975).

${ }^{2}$ Individual transferrable quotas (ITQs) as a form of privatization have been advocated for certain fisheries in British Columbia by some economists and opposed by others. ITQs have been implemented for halibut in British Columbia with the cooperation of current licence holders whose licences became far more valuable under the new policy. ITQs have been vigorously and consistently opposed by industry leaders and by crew and rental skippers whose method of payment has been transformed from an established share system to a lower wage (Cruickshank 1991). ITQs do extend the fishing season and market availability in fresh form for fish accessible for long periods, such as halibut. This advantage would not apply to the short availability and seasonal fluctuations of salmon. For these and other reasons, ITQs are not discussed here.
}

ernments acting alone. Limiting access can be a problem not only in the case of unlicenced fishers, but also for both the legal and illegal activities of licenced fishers. With thousands of licence holders in possession of highly sophisticated harvesting, refrigerating, and freezing technology, it is difficult for government to make sure that salmon are actually caught in the areas and times that are reported. (This applies to licenced and unlicenced recreational marine and all riverine fishers as well).

In addition, if thousands of fishers can harvest every local area of the coast to the same degree, there is little incentive for fishers to work on improving the productivity of specific areas. Moderate improvements in abundance might not be adequate to create a harvest "opening"; dramatic improvements might be wiped out in a single opening. In the latter case, benefits might be too widely shared to merit the continued hard work of those focused on particular areas.

Community-based regimes can be very effective at controlling access to the nearshore resource, and co-management regimes can greatly improve more distant water enforcement (Jentoft and Kristoffersen 1989; Pinkerton and Keitlah 1990). The community of members of locally based associations, First Nations, licence holders in a particular area, and/or simply knowledgeable community residents who know who can fish, add greatly to the capacity of locally based regimes to control the access of illegal fishers. Such local management systems can also devote much energy to management with some sense of security that they will enjoy some of the benefits. When a locally based regime has gained widespread community support and legitimacy, and there is a sense of ownership and responsibility for the resource among a known group of users, the entire community can become part of the eyes and ears of the local regime's enforcement (Pinkerton and Keitlah 1990). At the opposite end of the spectrum where these aspects of the management system are absent, one is more likely to find situations like the one documented by Kearney (1983) in Nova Scotia: Atlantic herring (Clupea harengus) quota holders and processors underreported deliveries by $40 \%$ during a crisis when DFO was blamed for resource problems and price failures.

(2) Subtractability. Common-pool resources are also problematical to manage because the harvesting activity of any individual subtracts from what is available for any other user. Average catch declines for every fisher when one more fisher enters the fishery or takes a bigger share.

Community-based regimes can limit the harvesters in any particular area to a number that can be sustained by the resource. The willingness of fishers to obey the rules appears to be related to their ability to monitor each others' activity to insure that everyone else is obeying the rules also (Ostrom 1990), as well as the degree of legitimacy of the regime, as mentioned above. When the fishing regulations are issued or validated by a locally based regime, in consultation with government and following principles of sustainable yield, and when a diversity of local people are knowledgeable about the conservation imperative of regulations and able to observe each others' behaviour, regulations will be more easily implemented.

It is important to note that this does not mean all community-based or artisanal fisheries automatically operate in this way. Cultural ecologists have observed that smallscale societies tended to develop stable human-resource 
relationships in the first place only when there was a long period of adaptation, during which a community could learn by trial and error to live within the carrying capacity of the local environment (Lee and DeVore 1968). In this process, the resource must be somewhat "forgiving" so that people can learn how to limit their access appropriately before they do permanent damage to the resource (Pinkerton 1994a). Selfmanaging regimes survive in modern times only if they can continue to discipline their own members, and protect the resource from overuse by "outsiders" operating under a different system. Because of the difficulty of achieving this under conditions of resource competition in modern times, self-managing regimes tend to survive in more isolated areas, or in areas where the state has not been able to play an active role (e.g., Stoffle et al. 1994). More frequently, self-managing systems have either collapsed under pressure or evolved into some form of co-management (Pinkerton $1989,1994 a)$. In the ensuing discussion of self-management and co-management, it is useful to conceptualize co-management as 8 potential points on a 10 -point continuum between state management (at point 1) and self-management (at point 10). In this discussion, self-management will be useful more as a conceptual tool than as a description of an operating system. This discussion also uses the term "comunity-based regime" to refer to forms of co-management that have an important component of self-management.

Common pool theorists, (Ciriacy-Wanthrup and Bishop 1975, Feeny at al. 1990) have pointed out that the type of resource regime or system of property rights under which a common-pool resource is managed has a great deal to do with success in dealing with the nonexcludability and subtractability issues. Resources managed actually or virtually as open access (no regulation) have usually collapsed tragically, as Hardin (1968) predicted in the original paradigm.

Resources managed by state regulation sometimes collapse because of inability to sufficiently exclude or to regulate the activities of users, as mentioned above. State management may also be vulnerable to political processes or government failures, which lead to suboptimal management or complete elimination of the resource (Feeny at al. 1990). The widely documented disappearance of aquatic species around the globe, related to both overfishing and failure to protect habitat, does not provide reassurance that most nation states are able to manage effectively (IDRC 1991; Larkin 1991; Nehlsen et al. 1991; Pitt 1993).

Resources managed under communal or community-based tenures (or mixed community-state tenures) were not considered by the original "tragedy of the commons" paradigm, although these are common throughout the world both as traditional regimes that operate without interference, and as mixed regimes that operate informally or formally under contractual arrangements with state governments (Martin 1989,1992 ). A key difference in community-based regimes is that information about harvesting and habitat-destroying activities tends to be widely shared and mutually monitored by community members, i.e., there are no secret "free riders" disobeying harvesting regulations. Habitat destroyers will be subject to more concerted political pressure.

These regimes thus operate on a fundamentally different dynamic than the one imagined by Hardin, in which each individual user acted alone, in competition with, and in isolation from, other users. Hardin and his followers used the theoretical "prisoners" dilemma" situation to predict that individuals under state management would act out of a narrow individual self-interest. ${ }^{3}$ A key feature of the prisoner's dilemma is the lack of information each harvester has about the intentions of the other harvesters, and the inability to affect the behavior of the other harvester. In a communitybased regime, the "prisoners" or individual harvesters do not act out of ignorance or impotence regarding what other harvesters will do, but are part of the system that monitors and forces compliance on other community members.

Shared information creates opportunities for local groups or state-local bodies to create rules for self-regulation and to enforce the rules. Under appropriate conditions, as discussed above and below, such groups can be successful at dealing with the nonexcludability and subtractability issues. Furthermore, community-based groups in this situation can become proactive, rather than merely reactive, educating their members about resource problems and taking responsibility for solving these problems (Osborne and Gaebler 1992). While it would be a mistake to consider the community-based aspect of co-management an automatic panacea for the array of fisheries management problems, it would be equally unfortunate not to take advantage of the management benefits available under community or mixed community-government arrangements, particularly at a time when DFO resources for management are being cut back.

What is needed is a framework for analyzing the key elements of successful self-management systems, especially as incorporated into a co-management regime. The next section will begin to construct this framework through two illustrative examples.

\section{Experiences with Community-Based Management and Self-Management}

The two examples below illustrate some of the general characteristics of traditional self-management regimes. Such regimes tend to involve culturally distinctive methods of regulating access to resources, sustainable yield harvesting strategies, habitat protection, and social systems of production, distribution, and consumption that support sustained yield in balance with other resource uses. The management system is reinforced by systems of language, ritual, and spiritual beliefs that shape the interpretation of environmental experience and knowledge. Self-management also includes the notion of the community as a corporate group linked to specific lands and marine areas in a relationship which persists over generations. The corporate group has the ability to exclude, regulate, or monitor the impact of non-corporate users on local resources.

(1) Small community management of inshore and nearshore areas in Lake Titicaca, Peru. Comparing 151 fishing communities along the Peruvian shore of Lake Titicaca in the size and type of their locally controlled territories, LeVieil and Orlove (1990) noted three common characteristics. (1) Communities were able, despite government opposition,

\footnotetext{
${ }^{3}$ In this hypothetical model, two soldiers out of uniform are captured by the enemy and interrogated separately, without being told whether the other prisoner has confessed or not. The model predicts that each prisoner will "defect" in exchange for a reduced punishment, through fear that the other prisoner will do the same. The parallel is then drawn with the harvesting of resources such as fisheries, in which each harvester will overharvest, for fear that nobody will effectively prevent others from doing it.
} 
to assert territorial control (exclude outsiders and regulate insiders) over their local areas, averaging $6 \mathrm{~km}$ of shoreline and $30 \mathrm{~km}^{2}$ of aquatic zone; outsiders are repelled by threats or by destruction of gear. (2) The type of control depended on the costs and benefits of defending the territory: the surveillance, defense, and retaliation costs increased with the distance offshore, so that inshore and nearshore territories were defended more rigorously; offshore areas were defended only periodically, when schools of fish passed through. In offshore areas, outside fishermen recognized the informal local rights by giving the local community a small portion of the catch or comparable commodities. These arrangements were less costly and more beneficial than strict policing of offshore areas. (3) Fishermen received more of the benefits from territorial defense of fishing grounds and also paid more of the costs in time and risks associated with defending the territory than did other community members.

(2) Reef Management by Clan Chiefs in the South Pacific (Johannes 1978, 1981, 1988; Klee 1980; Ruddle and Johannes 1985; Iwakiri 1983; Carrier and Carrier 1989). These are some of the most thoroughly documented cases of selfmanagement. Johannes' now classic Words of the Lagoon (1981) records 16 mo of fieldwork on local fishers' knowledge and management of reef species, during which he fished with and was tutored by the local fishers. Johannes documents not only Pacific islanders' encyclopedic knowledge of fish behaviour, but also the sociopolitical measures taken to regulate land, water, and resource use and achieve conservation in these complex and fragile ecosystems.

Johannes $(1978,1988)$ later extended his studies to generalize about the management measures used in many parts of Oceania long before they were considered in western management. These included limited entry, closed seasons, permanently protected reserves, size and area restrictions, gear restrictions, restrictions on taking eggs, allowing for escapement, holding excess catch live in pens until needed, and taboos on eating certain species. These measures were enforced through a system of marine tenure similar to the one described for Lake Titicaca, except that fishing rights were controlled by clan chiefs for the benefit of the municipality. Outsiders who had failed to ask permission to fish in the local territory (and offer a portion of the catch) were fined through their chief.

\section{Experiences with Joint Community-Government Management or Co-management}

Many traditional management systems, such as the South Pacific example, have weakened or collapsed under political domination or pre-emptive fisheries by colonial powers or national governments. In some cases, the authority of chiefs or the local group to regulate a local fishery was eroded directly by the activities of more powerful outsiders. In such cases, local group members might choose to respond to external markets and no longer be subject to local control. Missionaries sometimes directly attacked the ideological basis for traditional management through attempts to discredit the cultural belief system. It is, therefore, important to consider the two following examples in which, instead of collapsing, a local management system has been incorporated into a modern state, and allowed to operate virtually unchanged. These examples illustrate how the essential features of the traditional systems function in a modern context.
(1) Village multisector co-operatives in Japan (Commitini 1966; Ruddle and Akimichi 1984; Ruddle 1989; Short 1989). The Japanese system of communal sea tenure has remained intact from traditional to modern times. It has the same legal status as communal land tenure. Based on an ancient system of clan ownership and control of the local marine area, sea tenure was incorporated into Japanese law in 1901 (updated in 1949) through what had by then evolved into local village-based fishing co-operatives. All coastal waters except port areas and industrial zones are owned by fishing co-operative associations or federations thereof. All locally resident fishers who are members of their local co-operative and work 90-120 d a year (depending on the cooperative) enjoy rights to fish particular species in their area (Ruddle 1989). In addition, the prefectural government (equivalent to a county or regional district) grants a very limited number of licences to large-scale set-net locations for herring and salmon fisheries if there are appropriate locations for them. Small set nets for these species are allocated and managed by the co-operative. In some co-operatives, some waters may be reserved for the use of a particular fishery, such as set nets or octopus holes, which are sometimes inherited; highly productive areas may be allocated by lottery. Fishing rights cannot be loaned, rented, mortgaged, or transferred by individuals. Any infringement or loss of these rights by the co-operative must involve compensation to it. (In one industrializing area, industry compensated fishers in the cooperative for the destruction of their fisheries (Befu 1980). The frequent failure to protect habitat from industrial pollution is the one serious shortcoming (Wigen 1989).

The local co-operatives manage their areas by implementing and enforcing national fishery laws and regulations (e.g., that harvest levels be sustainable), supplemented or complemented by those made locally. Local regulations involve conservation measures and membership. The co-operative meets with prefectural and national governmental offices to obtain approval of its regulations and to negotiate licencing and other rights. Although ultimate control of a co-operative rests with a general membership assembly, daily business is conducted by an elected executive committee, including one or two paid administrators. These work with sectoral fishing groups, which make recommendations about how to implement regulations in their particular fishery. Some co-operatives with highly diversified fishing sectors might more properly be considered multiparty co-management. However, because analysts believe the high level of compliance results more from informal social pressure than from formal enforcement (Kalland 1981), this classification is not used here. Consensus decision making must meet the goal of accommodating in some way the interests of all concerned. The Japanese local management system has been remarkably stable over time, and has been able to accommodate highly productive aquacultural innovations in species such as geoduck and scallops.

(2) Community enforcement of individual access: Maine lobster. The lobster "fiefdoms" of the state of Maine constitute an informal community-based marine tenure system that has recently gained some degree of state support (Acheson 1975, 1988; Bowles and Bowles 1989). Lobstering communities in the more isolated outports of Maine are more successful than less isolated areas at defending their territories through a system of limiting access to community members. Community members constitute a "harbour gang" 
that not only limits to gang members those who can claim a local lobster territory, but also enforces the rules about respecting other members' territories on all lobster fishers. Although, technically, anyone can buy a lobster licence, lobster fishers who defy local customary rules do not last long. Destruction of gear is the chief method used to censure those who intrude on an individual lobster fisher's "fief" or those who fish the area without participating in the local gang that allocates the fiefs. Fishers in the better defended outport areas enjoy a far higher catch per unit of effort, because the mean lobster size is much larger and they make fewer trips to collect them, having exclusive use of their territory.

The lobster example illustrates a common feature of forms of self-management regarding more stationary resources such as shellfish. Management rights in these more predictable resources tend to be individually held, while in the same area rights over less predictable, mobile resources are communal. The same patterning of individual and communal rights is also found in Lake Titicaca and Japan as well as in other fisheries and in terrestial common pool resources (LeVeil and Orlove 1990; Netting 1976; Ostrom 1987).

However, in the Maine lobster case as in other selfmanaging systems, individual rights exist in the context of local community rights, and are upheld by them. In recent years, harbour gangs have produced regulations on closed seasons and trap limits, which they have persuaded the state to adopt. Harbour gangs favoured trap limits to be set at different levels appropriate to each region. Limits were brought in by government based on specific agreements with lobster licence holders in particular areas. The existence of state regulations lowers the monitoring and enforcement costs of harbour gangs, and serves as an important support to the local informal management system. A large degree of self-regulation by the harbour gangs likewise lowers the cost of enforcement by the state.

\section{Experiences with Multiparty Co-management}

(1) Self-regulating, multistakeholder watershed-based users' associations: southern California groundwater users (Blomquist 1992; Ostrom 1990). Self-management and co-management systems can also arise in the absence of a shared tradition, social system, or religious system, as illustrated by an example outside the fishery, used here because of its longevity and institutional evolution. A compelling economic need to sustainably manage scarce groundwater forced local users in southern California in the 1940s to work together. Basin by basin, watershed by watershed, they crafted self-governing institutional structures that have proved highly successful to the present day. These are based on the ability of users to monitor each others' use and have mutual accountability through a hired co-ordinator, the watermaster.

Groundwater users in the Raymond Basin near Pasadena were the first to innovate; neighbouring basin residents learned from them and followed suit. Raymond Basin faced salt water intrusion into underground aquifers because of competitive and nonsustainable use of groundwater, high costs of litigation among competing users, and high costs of importing water if the basin were irreparably damaged by overuse. By reaching out-of-court agreements and jointly hiring a watermaster to monitor and enforce the rules they agreed to, the many small individual users and the larger water companies achieved a guaranteed and sustainable supply of water at a much lower cost.

Key to the successful establishment of self-managing water users associations were public discussions among users, joint commissioning of studies, and considering options, e.g., how individuals were likely to behave in response to various strategies, and to what behaviours individuals were willing to commit themselves. Once these commitments were made, the costs of mutual monitoring and enforcement could be kept quite low. The watermaster was directly accountable to the users, and a user who practiced noncompliance would have a great deal to lose. (It is important to consider what fisheries offer opportunities to keep monitoring costs low by mutual monitoring, and which offer greater opportunities to cheat. The salmon fishery falls into both categories at different times and places and might require a diversified monitoring system in which mutual monitoring could play and important, but perhaps not exclusive, role.)

During the first $40 \mathrm{yr}$, the Southern District office of the California Department of Water Resources served as the Raymond Basin watermaster, and the water users paid only $50 \%$ of the management costs. In 1984, the Raymond Basin Advisory Board, which had become increasingly active in seeking innovations and learning from activities in other basins, took over the administration and $100 \%$ of the costs of management. The management board, henceforth, comprised 10 water users' representatives and normally operated by consensus. It retained the services of the Department of Water Resources under contract for the preparation of annual reports and other support services, as required by the court, which retained jurisdiction to decide future controversies and to rule on alterations to institutional structure such as the above. Since 1984, the management board has attempted to manage the basin with more precision and to experiment with more flexible arrangements for water storage, credit spreading, and voluntary pumping pattern adjustments. As other water basins established their management structures, the water boards have formed networks that have exchanged and shared services. The management program has stopped the overdraft of water without ever having to use sanctions to enforce the injunction against overpumping in nearly a half century. The system has kept administrative costs low and shown considerable adaptibility to changed basin conditions and new ideas.

This example suggests that enormous differences in levels of investment and in technology used, such as exist among different gear types in the B.C. salmon fishery, need not be an impediment to achieving agreement. What was crucial was the public discussion and exploration of goals and possible strategies, the support of government in facilitating the acquisition of key information about the status of the resources and the risks involved in various strategies, and the role of the courts in ruling that each user must share equally in reducing use by $31 \%$, regardless of seniority. These three conditions allowed users to move beyond a prisoners' dilemma situation in which each party acts out of solitary ignorance of both other parties' intentions and the state of the resource. Without access to critical information (such as information on particular stocks), and the ability to make informed decisions about long-term costs and benefits, First Nations and stakeholders are not likely to form the 
alliances that lobby for reform and effective regulation. Without access to forums in which they can interact creatively with one another and commit themselves to mutual planning and monitoring, they will not form self-regulating associations.

Locally based management agreements that involve different gear groups, sectors, or differently situated parties can still be based on the same principles as the above arrangements, if they are area based or ecosystem based. Several variations on this theme are presented below. The first example is more regionally based than ecosystem or watershed based, and hence requires more time and effort without these natural unifying forces.

(2) A Fishers' regional enhancement association (Amend 1989; Pinkerton and Langdon 1987; Pinkerton 1994b). The Prince William Sound area of Alaska, and the fishing community of Cordova in particular, led the state in lobbying for legislation to permit the setting up of fisher-operated nonprofit associations that could borrow money from a revolving state fund to finance the construction and operation of hatcheries and other salmon-enhancement projects. Projects were developed by the fishers' associations and approved by the Alaska Department of Fish and Game. The "aquaculture" associations basically practice cost recovery enhancement in a manner that dedicates two thirds of the enhanced returns to the "common property" offshore fisheries by their own members, and one third to the association, which catches the fish terminally and sells it to support the activities of the association. (The association also develops regional enhancement plans for its area jointly with the state.)

There is only one association per fishing area, and association membership is limited to the fishers licenced to fish in Prince William Sound, one of six salmon fishing areas in Alaska. Alaska has a system of licence limitation by area, although fishers may own licences in more than one area and do not have to be resident in the area they fish. In practice, fishers tend to fish only one area per species. Those licenced to fish in a particular area, therefore, have an incentive to build up the runs in that area, and do not have to share the benefits with an Alaska-wide fleet which has done nothing for the local area. There are approximately 200 seines and 500 gillnets licenced to catch salmon in the Prince William Sound area.

The association was originally formed by majority vote of the fishers, who then elected a representative board to run the association and hire staff. The association in Prince William Sound is run by a board of 43 (of which 23 are fishers), which meets in January, June, and September. One third of the board is elected each year by all licenced commercial fishers in the area. An executive committee is elected by the full board every June, meets monthly or more often, and distributes minutes and a monthly newsletter to the other board members. The full board sets general policy and the executive committee implements it.

The association was so successful in the enhancement of pink salmon that its sales of one third of the returns enabled it to begin supporting management activities for which it took responsibility alongside the state. For example, the association developed a plan for the allocation of enhanced salmon between seiners and gillnetters, the two major gear groups involved which participated equally on its board. The association planners forced small groups of seiners and gillnetters to work together until they reached some working agreements on what would constitute fair allocation. These groups then reconvened in larger sessions and developed an area-wide allocation plan that had widespread support.

The association also developed a co-ordinated harvest management plan for wild and enhanced pink salmon stocks. As concern developed in the early 1990 s about the potential impacts of a mixed stock fishery at one entrance to Prince William Sound, the association dedicated more money to tagging, tag recovery, and escapement counts; the entrance mixed-stock fishery was closed by 1993. In short, a fishers' association that began as a body dedicated to enhancement began to take on more and more harvest management responsibility as their successful operation became established.

Although the legislation required that a majority of board members be commercial fishers, the association boards were also required to represent fishing-dependent communities in the area, and Native corporations. This meant that the fishers' interests had to be tied to the interests of local communities, even if they did not live in the area. A sizeable minority of licencees in Prince William Sound in fact do not live in the area, and are thus less likely to attend all the board meetings and influence the association. Because of its ability to include the interests of both resident and nonresident users, the association offers a helpful model for a situation like the one in British Columbia, in which fishers may have long-term ties and dependencies on fishing areas distant from their residences.

Although local residence is an ideal condition for the development of community-based management, the Alaska model suggests that it is not necessary for all users to be resident as long as there is a core group of active residents involved in management who are accorded, at least informally, a special status based on stewardship. The communitybased development that is likely to emerge from local enhancement activities (see below) may also encourage more of the stakeholders to relocate to the area.

(3) Watershed management by multiparty local committees (Pinkerton 1991; Dobyns 1992; Seiter 1993). While the Alaska model illustrates that regional multiparty salmon management is possible, a Washington watershed planning model illustrates how different interest groups can work together effectively on a smaller watershed level, especially with the benefit of some education and guidance from a co-ordinator. The model is especially useful as an illustration of effective mechanisms for achieving consensus, legitimacy, and volunteer contributions. It eventually evolved into a forum in which tribes operated as governments, but planned jointly and through consensus with other watershed interests. Their activities focused in this case on habitat protection rather than harvest management.

Because of increasing concern in Washington State about the pollution of Puget Sound, the Puget Sound Water Quality Authority was set up as a superagency in 1985. In 1987 the Authority initiated a nonpoint source pollution control program to stimulate local planning to implement statewide water-quality standards. The agency targeted key watersheds with valuable salmon runs or shellfish-rich estuaries; it asked counties to convene local representative committees (including tribes and nontribal commercial fishers) from watershed residents. Each county hired a co-ordinator to select a local planning committee, and to assist the committee in producing a water-quality plan. This plan set target community water-quality standards, and a method and 
timetable for achieving these standards. A comparative study of nine such planning processes (Pinkerton 1991) suggested that, where there was an effective local co-ordinator who combined education about water quality (sources of pollution, known methods of reducing pollution) with creating dialogue and a problem-solving approach among members, the planning process was quite successful in creating a consensus about how to priorize and address pollution problems, and an action plan for implementation. The planning process was successful also because it operated within a clearly defined mandate which empowered the county to require compliance from other agencies, once the plan had gone through an approval process. Typical actions taken under the successful plans included (1) farmers fencing cattle out of salmon streams, resulting in lowered erosion and pollution; (2) septic tank upgrading, resulting in lower fecal coliform counts; (3) higher than state standards set for logging in the riparian zone, resulting in greater streambank stability, shading, and large woody debris to create pools; and (4) co-operative stream restoration or enhancement projects, beach clean ups, or safe toxic waste collection and disposal days, using community volunteer labour.

The combination of having a powerful mandate and achieving local consensus by a democratic process gave the plan a high level of legitimacy and support. This generated a local constituency that could apply pressure on local agencies to implement the plan, as well as existing regulations (currently unenforced). This latter process happened most notably when a corps of local volunteers was trained and organized to carry out projects in the watershed and to educate the rest of the community on water-quality problems and solutions. In terms of fish habitat protection in particular, the water-quality planning process at the local watershed level was a very effective tool in creating the political will and support to make habitat protection more effective. Volunteers reported violations and worked on major stream projects, including rechannelling to avoid major pollution sources.

Even more important, a plan on the watershed level can deal with diverse sources of nonpoint pollution in a comprehensive way. The regulatory framework of government agencies often does not permit the cumulative effects of many different sources of pollution, normally regulated by different agencies under different laws, to be dealt with in this way, and fish managers do not have the staff to cover it.

The processes begun by watershed-based water-quality planning were continued through a second process to solve water allocation disputes among multiple parties in one pilot watershed, the Dungeness-Quilcene on the Olympic Peninsula. In 1990 the statewide Chelan Agreement brought together tribes, agriculture, fisheries interests, recreation interests, power companies, other industrialists, and the affected state agencies. Their agreement in principle about how water could be equitably shared is in the process of being tested in this pilot project (and one other not discussed here).

The Dungeness-Quilcene watershed planning process is of interest to this discussion chiefly as a model for how tribal governments can fit into a government-multiparty process. This exercise occurred after the Centennial Accord had been signed, which recognized tribes as sovereign governments, and affirmed the government-to-government relationship between state government and tribal governments. In the Dungeness-Quilcene project, the Jamestown S'klallam Tribe acts as local government and co-ordinating agency, playing the role parallel to that played by the county in the waterquality planning process described above. Because several of the county commissioners in this watershed had also been previously involved in that successful water-quality planning project, their willingness for the tribe to be co-ordinating agency indicates a vote of confidence that the tribal interest is likely to coincide with the self-interest of people in the watershed as a whole. All the meetings are held on the reservations in tribal facilities.

For the other committee members, the original structure of decision making envisaged by the signatories to the Chelan Agreement, and suggested for the pilot projects, was not acceptable. According to this model, a decisive vote on the committee would have involved the agreement of all three governments (tribe, county, and state agencies that are led by Department of Ecology) plus three out of the five local interest groups representatives. The interest groups (recreation, fisheries, environmental, business, and agriculture) would not accept the possibility that "governments could gang up on us," and insisted that all decisions be made by consensus. This has been accepted for the present, with the proviso that the statewide decision-making method might be reconsidered if reasonable progress cannot be made with consensus. This model is important as an acknowledgement that, even if some parties have greater or prior rights, the interests of effective management require that they all work together.

(4) The importance of habitat as the overriding common interest (E.W. Pinkerton, unpublished data). These two watershed management models are key examples of the importance of habitat protection as a common focus for stakeholders who may be in conflict over other issues, such as allocation. Because these groups were initiated for the purpose of resource protection, and after major fisheriesallocation battles had been settled, it was easier for groups to focus on their more fundamental common interest in healthy habitat. This possibility has been realized at the watershed level among all stakeholders, but sport and commercial fishers have not joined habitat protection efforts at the state level in a significant way. ${ }^{4}$ Partly as a result, the focus of the Washington Department of Fisheries on habitat has not been a strong priority, and support has been fragmented.

The tribal-nontribal allocation battles and the tribal-state power battles from 1970-1985 in Washington State (surrounding the 1974 US versus Washington case, its appeals and implementation) created a major distraction from habitat issues (Bruun 1982). Enormous effort was put into developing a salmon harvest co-management plan for Puget Sound, adopted by the state and tribes in 1984, in which the tribes and Washington Department of Fisheries shared power at each stage of planning (Cohen 1986, Pavel 1989). The tribes fought hard, and often successfully, for greater attention to management of individual stocks or stock groupings, especially after they had won a court ruling (Hoh vs. Baldrige

\footnotetext{
${ }^{4}$ Sport and commercial fishers could participate at a statewide level through raising fish habitat protection issues at meetings of the Pacific Fisheries Managment Council or the Forest Practices Board or working with the tribes or environmental groups who have participated in the Timber, Fish, and Wildlife Agreement since 1986. Trout Unlimited, a sportfishers' group which has participated in the latter forum, and recently Washington Trout, are notable exceptions.
} 
1981), which recognized the right of each tribe to force management attention to its own local fishery and its stocks. The tribes also took these battles to the Pacific Fisheries Management Council (involving ocean interceptions) and the Pacific Salmon Commission (involving international interceptions), but they had to compromise with their state comanagers and other parties more interested in mixed-stock fisheries (Pinkerton and Keitlah 1990). Some tribes also felt that they should not have to pay the entire price for past management shortcomings by being the only party without some mixed-stock fisheries or some dependence on hatchery stocks. These tensions eventually created a complex co-management system with a high level of data, co-operation, and sophistication in harvest management.

The tribal-state co-management system fared less well in habitat protection, even though a major effort was launched by tribes and environmental allies to reform logging practices in 1986 (Pinkerton 1992). By the time the loss or endangering of salmon stocks had been documented and related in a more systematic way to habitat loss (Nehlson et al. 1991; Bisson et al. 1992), the trend had become difficult to arrest or reverse. By 1993, all the coho salmon (O. kisutch) stocks in the Pacific Northwest were under petition by environmental groups for listing under the Endangered Species Act. By 1994, nine additional (non-coho) Puget Sound stocks were petitioned for listing by an association of employees of the Washington Department of Fisheries, and environmental groups were preparing even more petitions. An endangered species listing would force management agencies to terminate virtually all fisheries that could impact the listed species, causing a major disruption to normal fisheries. Greater concern about stock status caused the Pacific Fisheries Management Council to close ocean fisheries completely in 1994. Many scientists fear that cycles of low ocean survival and unfavourable climatic conditions (which have occurred before) are now so exacerbated by loss of habitat quantity and quality (a new condition) that a number of depressed stocks will not rebound when ocean survival improves (Lichatowich 1994; Seiler et al. 1992; Lawson 1993). There may indeed be, as Alverson and Larkin (1993) warn, "much more to worry about from habitat degradation than from overfishing."

Habitat is an overriding concern because fish as a common pool resource are always situated within another common pool resource, water: fish are a commons within a commons, as R. Bish notes (personal communication 1994). Competition for water use comes from actors far more powerful and threatening to fisheries than groups of fishers (Bruun 1982): hydro-electric companies, multinational aluminum and timber companies, heavy industrial polluters, real estate developers, and irrigators. There is little doubt that, in the end, nontribal commercial and sport fishers will have suffered as much or more from habitat loss than from sharing $50 \%$ of the resource with the tribes under the 1974 U.S. versus Washington decision. The tribes and all fishing-dependent communities have lost a great deal as well: Bill Smith, the first chairman of the Northwest Indian Fish Commission (the umbrella group which co-ordinates tribal fishing issues among tribes) notes that " $50 \%$ of zero is zero", adding that "the cost of those battles in terms of lost humanity of people to people is terrible." Smith's insight is shared by many scientists who agree that the solutions to habitat protection will require nothing less than fundamental changes in human attitudes and social structures (Lawson 1993; Alverson and Larkin 1993).

The success of watershed planning exercises suggests that one of the most direct ways for habitat protection efforts to be effective is to unite fishers, and other watershed users and landowners, around specific watersheds where they can best see their common interests, and build the human relations that enable effective common action. To affect policy statewide, however, local efforts must be co-ordinated. Although local planning has involved some individual fishers, their involvement has not been extended to the state level. At the state level, the main habitat protection efforts in Washington have been led by statewide tribal and environmental umbrella groups, with little support from commercial and sport fishers. Therefore, much of the support that was forthcoming has focused on wildlife and endangered species protection.

Fishers would do well to take the lead in fisheries habitat protection; if environmentalists take the lead by default, they are likely to have different agendas than fishers in protecting salmon. Some agendas could potentially create even greater management difficulties than already exist. It is crucial for all fishing sectors to see their differences within this larger perspective. The Washington experience suggests that if fishers do not unite around their common interest in protecting habitat, they will not only lose major portions of the resource forever, but they will lose control of the habitat protection and biodiversity agenda. These will be major future issues in B.C. as population expands and as competing demands on water and fish habitat increase.

\section{Conditions For Successful Co-management of Fisheries}

The variety of models for multistakeholder co-management show that the problems addressed by locally based regimes may be approached in a number of ways. There is not one way, and there may not even be a best way. However, the features that are widely shared in the models suggest that they are good predictors of success. In addition, systems work better when they have multiple reasons to work: when they perform multiple functions and have multiple forms of support. The following sets of conditions are identified as the ones most key to successful arrangements. They should not be viewed as absolutes, but as cumulative elements which work in tandem with one another under the general principle: the more conditions apply, the better chance there is for success.

Success is more likely when certain logistical problems are solved:

(1) Clear boundaries. Incentives for local stewardship of areas are stronger when boundaries are clearly delineated. The ability to exclude at least some users from local areas creates a greater sense of ownership and responsibility among local users. There may be benefits to setting aside some areas for the exclusive use of groups that can easily defend and regulate them for specific purposes (or the boundaries could be enforced by government, with assistance from local bodies and citizens). Different boundaries could exist for different purposes. Clear boundaries were a feature of all seven examples discussed above. 
(2) Clear criteria for membership or participation in local area management. Membership in local associations or in local watershed management boards, which could grow out of associations, need not be limited to local residents in the beginning, or perhaps ever, as illustrated in Prince William Sound. Local residents, both First Nations and non-native, could be considered to have the greatest stake, however, and thus have more influence on decisions. This would be especially true in areas where local residents have no alternative sources of employment and are particularly resource dependent. The greater role of local residents could be recognized either through the structure of representation on local management boards, through a co-ordinating agency role, some degree of veto power, or a host role as defined by some First Nations' customs. Clear membership criteria was a feature of all seven examples above.

(3) Management units of a scale appropriate to human resources and the ecology of any particular area. Examples showed that local stakeholders tend to protect and manage resources within their territory in proportion to the costs and benefits. Different size areas may be defended or managed in proportion to their proximity or their value during particular times, as evidenced particularly in Lake Titicaca and Maine. There are trade-offs between management units being small enough for easy monitoring by community members, and large enough for more comprehensive management of interacting sets of stocks.

Ideally, management units would be based on watersheds, combinations of watersheds, or coastal zones. They could include both exclusive and in-common areas for different users and purposes. For example, certain in-common areas could serve as buffers to equalize fishing opportunities when some areas have suffered relative scarcity, or when an unusually large run is concentrated in one area and a larger fleet is needed to harvest it. The appropriate scale for management units ideally would evolve from larger units to smaller units when and if the capacity and desire develops among local populations to manage smaller units.

Because the success of any local management system would depend vitally on the active support of local fishers and communities, these parties would be in the best position to propose and debate concrete options regarding scale. $\mathrm{DFO}$, or others, could then use computer modeling to project the specifics of these options, and to offer other options for public consideration. Any attempt by government to authoritatively designate specific areas would undercut the benefits discussed in this paper. Any attempt by government to use area-based management as a method of fleet rationalization would also defeat the purpose. In fact, area-based boards would be better situated than government to decide what the optimum number of fishing units should eventually be in their area. They would be motivated to consider resource sustainability, effective management, and the full range of community economic benefits. All seven examples discussed above were based on a concept of scale which balanced natural and human resources in one or more critical ways.

(4) Clear interception agreements. Local groups will not have incentives to do management planning, enhancement, or habitat protection if all the benefits of their efforts are captured by intercepting parties. It is in the interests of interceptors to allow enough salmon to pass through to terminal areas so that terminal residents of these areas will continue their work in rebuilding and stewarding particular stocks. Interception agreements must be worked out among all parties, before any rational planning can occur. These agreements could help frame other management options, such as those accorded local enhancement or habitat improvement associations. Principles used in the Pacific Salmon Treaty could provide useful models for interception agreements. For example, percentages of interception could change on a sliding scale depending on stock abundance, so that basic minimum amounts are assured to terminal areas. The sooner these agreements could be reached, the sooner local management options could be considered. This discussion assumes that international negotiations over interceptions through the Pacific Salmon Commission would continue as before, with probably greater inclusion of local board representation. With the exception of Washington State, this condition was not applicable to the examples discussed above.

(5) Local all-stakeholder co-management boards. The fundamental building block for co-operative management would be a local board with members representing all interested parties. Boards could provide the forum for discussion of all local fisheries management questions, the development of plans, and the review of management actions. Interested parties who would otherwise be disruptive are best brought into the process, if they are local stakeholders with legitimate concerns for the fisheries. The process would be most effective if it were set up so that all parties had more to gain by participating and working to solve problems together than by not participating or by attempting to disrupt the process, or using the courts. This means that some accommodation would have to be made for their legitimate concerns. Also, government would have to respect the integrity of the process, resisting the pressure of those who might try to circumvent or abort the process. At the same time, parties that came together would have to commit themselves to addressing basic resource sustainability problems, rather than acting merely out of a narrow and shortterm self-interest. This condition applied in some form to all the postindustrial examples, and in a general sense to the preindustrial ones.

(6) A co-ordinating role for a province-wide management board. An overall province-wide board could co-ordinate management through a coastwide stock management plan, dispute resolution between local boards, and major policy issues affecting the whole coast. For example, it could help select representatives to be included in the Pacific Salmon Commission negotiations. The provincial board would need to include representation from communities and regions alongside province-wide organizations that represent fishing organizations and tend to have a lower-mainland perspective. Part of the role of this board, however, would be to serve as a check and balance to the perspectives of local boards. This type of structure, or its equivalent, was present in the cases of Japan, the Washington State watershed planners, Prince William Sound, and arguably in the California groundwater users' case.

Success is more likely if some of the costs are assumed "in kind" (e.g., through contributed volunteer labour and materials) by local bodies, related to the assumption of certain responsibilities and the ability to generate revenue. This condition applied formally in the case of Washington State watershed planners, Prince William Sound, and California groundwater users; it applied informally in all the other cases. 
(1) Cost recovery related to local management activities. Legislation could allow local management boards and local enhancement associations to capture some of the benefits from local production, including enhancement, habitat protection, and, even more important, better wild stock management. Revenue could be raised through fish sales, landing taxes, licence fees, etc. These funds could be used to support operations, including hiring biological staff, collecting data in a fashion co-ordinated with other areas and DFO, possibly organizing or hiring support or substitutes for enforcement officers or related community projects. It would be important for local bodies to have the ability to borrow funds and receive partial funding for a start-up period, especially related to the hiring of a co-ordinator to help various participants work together. Aspects of this condition were present in the case of Prince William Sound, Washington State watershed planners, Maine lobstermen, and California groundwater users.

(2) A local volunteer force. A corps of local volunteers could back up and enhance the activity of full-time professionals. A diverse local management board with community representation, or the co-ordinator of this board, could arrange training and direction for a local corps of volunteers who could serve in several roles. They could assist in gathering information from other community members and from direct observation and then communicating it to enforcement personnel on violations of local management plans, whether harvest-related or habitat-related. Working with a staff biologist, trained volunteers could also perform important harvest monitoring and habitat monitoring services. Such a force would also play a key role in raising community awareness and support for excellence in management, and even help to create an important political constituency for adequate public funding for all management activities. This kind of recruitment of the community is possible with a sense of local ownership and responsibility for the resource, and a greater awareness of how local economies are tied to a healthy and well-managed resource. In areas where traditional aboriginal management systems are in place, the local board could assist in co-ordinating the activities of volunteers with theirs. This condition was present in Washington State watershed planning, and to some degree in Prince William Sound. It existed by implication among California groundwater users, and in different forms in Japan, South Pacific, and Lake Titicaca.

Success is more likely when certain objective political conditions are met:

(1) A degree of local control. When local association or management boards are allowed to exercise a sizable measure of control in "doing things their way", it is easier for them to generate support, enthusiasm, volunteer energy, and the sense of stewardship that constitutes the most important contribution of local management. In this way, existing social and political capital (local knowledge, experience, expertise, credibility) in the communities can be used and developed. Of course, local control in modern times and in dealing with migratory resources must have checks and balances through region-wide and senior governmental institutions, including DFO and the courts. The key to effective functioning would be flexibility and adaptability, as was demonstrated in the Southern California groundwater users' case. This condition applied to all the cases, although local associations or communities differed in the degree to which they shared power with regional or state-level institutions.

(2) Clear legal definition of local powers. Local bodies will take themselves seriously and put out more effort when there is enabling legislation or clarification of rights sufficient to give local management boards confidence that their work will not be disrupted by outside forces (e.g., regulation of other water users, conflicting jurisdictions) or dismissed as irrelevant or trivial (ministerial whim). This condition applied in Prince William Sound, California, Washington State, Japan, and eventually to some extent in Maine.

\section{The Importance of Social Learning}

Success is more likely if a social learning process occurs among different stakeholders, such as occurred with the southern California groundwater users and the Washington watershed planners. Social learning occurs when parties learn to redefine situations in terms of what they can achieve collaboratively. This involves not only a restructuring of perception, but also a willingness to take actions co-operatively with parties previously considered unknown and/or untrustworthy. Social learning can occur at both the provincial or state level and at the regional or local watershed level.

The California groundwater users example demonstrates that social learning among parties and stakeholders can occur without major government involvement, although the court ruling on equitable use reduction was critical in forcing one challenger to comply. Conversely, the Washington example shows that government involvement can be a powerful catalyst, and that having a convenor with appropriate stature, be it the national government, state government, country government, or tribal government, is one way of gaining some of the impetus, financial resources, and logistical resources to spur a collaborative social learning process.

Whether or not government is involved, the key question is: by what process do parties get beyond the "prisoners" dilemma" and learn how to work together? Useful responses to this question are found in several literatures, including the organizational behaviour, interorganization behaviour, and organizational learning literature in sociology (e.g., Argyris and Schon 1978; Gray 1985, 1991; Brown 1991) and the public policy analysis literature in political science (e.g., Reich 1988).

The first type of literature was usefully summarized and applied by Kofinas and Griggs (1993), which Pinkerton et al. (1993) applied in modified form to multiparty watershedbased collaboration. The basic "rules" for building multiparty collaboration can be summarized as: (1) having a convenor perceived to have appropriate stature, power, and purpose; (2) obtaining adequate representation of all relevant sectors; (3) finding a locally accepted basis for the legitimacy of participants; (4) finding a style of facilitation appropriate to the local situation; (5) establishing a shared definition of the problem; (6) establishing clarity about expected outcomes; (7) undertaking joint tasks, such as information searches, and assigning tasks to subgroups; (8) articulating the values that guide each party's interest in the process; (9) establishing and enlarging a common sense of purpose; (10) establishing formal rules about how decisions are reached; (11) establishing ground rules for conduct, and formally assessing the fairness of these from time to time; (12) inventorying all technical, financial, and human resources accessible to the collaborators; (13) negotiating agreement 
among collaborators; (14) deciding how to implement and monitor the agreement; and (15) creating a local constituency to support implementation.

While this approach may be especially useful in promoting social learning in collaborative watershed planning exercises, with or without government involvement, the broader process of social learning in the debating and building of public policy may be better illustrated in Reich's (1988) discussion of "civic discovery." Reich envisions government, or an objective third party, as a catalyst for policy building and problem-solving excercises. The catalyst could get all the options, their benefits, and drawbacks on the table and generate a process of civic discovery. It is through such public deliberation about what is good for society that opinions can be revised, premises altered, and common interests discovered. Reich identifies at least four kinds of discovery that may ensue from such public exchanges:

(i) The problem and its solution may be redefined. People may discover that their initial assumptions about the nature of the problem and alternative solutions are wrong or inappropriate. Conflict may be redefined as a project almost everyone can support, even if it was or is not their preferred outcome.

(ii) Voluntary action may be generated. Consideration of the plight of those affected may lead others to volunteer time and money toward helping them adjust to the solution. Their willingness to volunteer stems from the discovery that others are also willing to help. Without public deliberation, individuals or groups might not discover that they can voluntarily help remedy the situation. They might assume that their charitable impulses are not widely shared and that their individual acts would be futile. Discovery empowers people to take voluntary action together.

(iii) Preferences may be legitimized. People may discover there are many others who share their values about the public good, even though these values have not been adequately represented publicly by selected interest groups.

(iv) Individual preferences may be influenced by a consideration of what is good for society or the resource. If individuals and groups debate a policy outside the narrow confines of their own interests and lobbying efforts, and if they are required to make public their reasons for supporting a policy, they may be influenced by the process.

If these types of social learning or civic discovery were integrated with the findings of institutional economists and anthropologists (e.g., Ostrom 1990, Pinkerton 1991) and expressed as progressive steps, the following would be likely to apply.

(i) Through discussion of available information, participants would define the major problems that have to be tackled and agree to work on these problems together.

(ii) Participants would openly discuss and debate alternatives about how best to solve the problems, and the roles they each might play in the solutions.

(iii) Participants would make public commitments about what each party is willing to contribute to the solution, after a thorough airing of alternatives.

(iv) Participants would work with a co-ordinator who is highly experienced in group process and interest-based planning and could assist them in identifying their significant shared interests and their mutual stake in the health of local stocks.

(v) Ideally (especially at the regional level) the co-ordinator would help stakeholders begin to work together by getting them involved in a series of small co-operative projects. This experience of working together would both develop some trust and understanding among participants, and also provide an early focus on practical, achievable tasks that illustate the benefits of all groups "putting the resource first." The experience of smaller projects would allow the groups to begin to see their mutual dependence in concrete terms, and to move toward taking on larger and longer range tasks.

(vi) The local management board should ideally be willing to set up a system of low-cost mutual monitoring by the parties or monitoring by a mutually acceptable party accountable to all. Such a system would assist parties in developing trust in management information and a sense of mutual accountability. Government authorities would need initial involvement to be satisfied that the system was workable, and would need longer term involvement in troubled areas.

\section{The Role of the Department of Fisheries and Oceans}

Obviously government would need to be involved in the type of changes discussed above, and could even be the sponsor and catalyst for the beginning of the process. However, government cannot be both the sponsor and the convenor, or the process will simply follow government's agenda, and fail to invoke trust and commitment from all parties. If government is involved, what is needed is a process and a structure managed from outside government, within which parties can work with each other and with government.

Fortunately, there are models both in Canada and the United States for how such a process can be successfully executed. In 1987 Labour Canada funded two of its former employees to set up an independent Public Policy Forum in Ottawa to bring government and the private sector together to identify and deal with contentious issues. Since then the Forum has assisted in setting up sectoral councils that take on issues in a more objective fashion than government or any sector can alone. Government usually contributes at least part of the funding to initiate the process, but the successful processes become mostly self-funding in a short time (Public Policy Forum 1993). A similarly independent policy forum to discuss fisheries management issues in British Columbia was initiated in 1993 by a former senior DFO employee and his associates. Housing itself at the Fisheries Centre at the University of British Columbia as the neutral forum, this Common Ground Project brings together perspectives from commercial fishers, sport fishers, First Nations, DFO, provincial fish management agencies, and the university. The group has formed an interim council and is planning its third meeting at this writing (Common Ground Project 1993).

In the United States, governments at all levels have experimented with various forms of contracting certain types of service delivery or policy-making roles to third parties: nongovernmental organizations, branches of local government, and private contractors. Often government sets general guidelines within which these organizations work, but lets them do the job as best they see fit. A team including a 20 -yr veteran of such experiments (Osborne and Gaebler 1993) claims that such partnerships deliver consistently better results at lower costs.

The example from their book most quoted by U.S. Vice President Gore in launching a 1993 U.S. federal program 
by the same title, "Reinventing Government", concerns how garbage collection was made more efficient in Phoenix, Arizona. In response to a tax revolt, the city government decided to open one district of the city at a time to bids on a 5-yr garbage collection contract for that district, allowing the city's Public Works Department to submit bids alongside outside contractors. To avoid layoffs of public employees, the city required private contractors to hire displaced Public Works employees, and transferred those who wished to remain in Public Works to other jobs. After losing the first four contracts, Public Works was forced to reformulate more efficient and effective strategies. Over a 10 -yr period it won back all the contracts and a higher morale among employees (Osborne and Gaebler 1993, p. 76-79). The example illustrates one of many mechanisms discussed by the authors for increasing accountability of government through creating incentives for delivery of appropriate service.

If salmon management did become more accountable, based on the development of policy and support by the fishing community, DFO would presumably continue to play a key role in the management system, in at least the following ways:

(i) DFO could be the party with ultimate responsibility for resource conservation and protection. It could reserve the right to intervene if it believed conservation was being compromised. Conservation standards and management objectives, goals, and procedures for specific areas could be spelled out in agreements between DFO and local bodies. All parties would be accountable to the agreement. As a practical interim arrangement, DFO could work closely with local boards until it was confident that procedures were running smoothly. Changes to annual management plans for each area could be negotiated annually.

(ii) DFO could be the provider of technical scientific expertise and advice, at least in the beginning. This means DFO would identify problems it sees and make data publicly available so others could verify that the problems were real. As technical expert, it would be important that DFO openly acknowledge the unknowns, uncertainties, and risks involved in any current or past policy or policy initiative. The fishing sectors and public should be asked to take responsibility for some of the risks in supporting a particular path of action.

(iii) DFO could be the catalyst (but not the co-ordinator or manager) of public and cross-sectoral discussion of the basic policy direction of management. This discussion is not about technical issues, but concerns what basic values and goals should drive the management system. In assisting in the development of a fundamental policy direction, the convenors should pay particular attention to fishing-dependent communities, the majority of which are not represented by current fishing organizations.

\section{Conclusion}

This discussion has examined the theory and the practice of community-based self-management and co-management in the light of its capacity to address the problems that plague the managers of common pool resources, such as dealing with the conditions of nonexcludability and subtractibility. Three types of elements key to the success of locally based regimes were identified: logistical, cost sharing, and power sharing. The social learning processes by which government and local bodies could move toward such regimes were also discussed.

Current managers, aboriginal peoples, and fishing sectors will eventually have to deal with these basic conditions, as well as the biological, economic, and political problems particular to the B.C. salmon fishery, if there is to be a resource in the future. This paper has explored various models and examples of multiparty co-management of fisheries, and suggested how elements of them could be applicable to the west coast salmon situation, helping to address the longstanding problems of this fishery. It was argued that co-management arrangements could contribute to improved data collection, analysis, and monitoring; they could lower the cost of fishing through more localized fisheries and lower the cost of management through cost recovery supported local management activities and organized volunteer efforts. Co-management arrangements could also contribute to the resolution of conflict among parties, and to the development of greater credibility of, participation in, and support for the management system. The analysis of existing cases suggests that such applications are possible, desirable, and could be part of a logical progression toward greater power sharing between DFO and fishing groups, as well as among different groups and sectors.

This progression would best begin with the public discussion and development of basic policy objectives for salmon management. The setting of goals and methods for achieving these objectives would then inform the process of deciding how the problems of the salmon fishery were approached. With a sense of greater security and predictability in clear policy objectives, fishing-dependent communities, as well as fishing organizations, could more openly consider the type of institutional possibilities discussed in this paper. The best supported and most effective policies and policy instruments are likely to be those that are thoroughly discussed and developed at the grass roots level. The institutions and processes for power sharing discussed in this paper are intended to suggest options that could be helpful in these discussions. One or several of these options, or combinations thereof, could be tried on an experimental basis by communities or regions interested in pursuing management improvements of the type described here. If some strategy for improvement is not developed, the fishery will be eroded by the combined biological, economic, and political problems previously identified.

\section{Acknowledgements}

The author warmly thanks Alan Greer, Guy Cookson, Don Cruickshank, Ron MacLeod, Dave Ellis, Skip McCarthy, Dave Moore, Hugh McNairney, and two anonymous reviewers for comments on earlier drafts and helpful discussions. The support of the Department of Fisheries and Oceans on an earlier draft of this paper, the support of the Social Sciences and Humanities Research Council of Canada on past and ongoing research, and logistical support from Westwater Research Centre is gratefully acknowledged. Of course none of the above are responsible for the conclusions or any errors.

\section{References}

ACHeson, J. 1975. The lobster fiefs: economic and ecological effects of territoriality in the Maine lobster industry. Hum. Ecol. 3: 183-207. ACHeson, J. 1988. The lobster gangs of Maine. University of New England Press, Hanover, N.H. 181 p. 
AKAHA, T. 1993. Japanese-Russian fishery joint ventures and operations: opportunities and problems. Mar. Poli. 1993: 199-212.

AlbreChT, D.E. 1990. Co-management as transaction: the Kuskokwim River salmon management working group. M.A. thesis, McGill University, Montreal, Que. 139 p.

Alverson, D.L. AND P.A. LARKIN. 1993. Fisheries: fisheries science and management-century 21 , p. 150-167. In C.W. VoIGTLANDER [ed.] The state of the world's fisheries resource. Proceedings of the World's Fisheries Congress, Plenary Sessions. Oxford \& IBH Publishing Co., PVT Ltd., Oxford \& New Delhi.

ARgYris, C., AND D. SCHON. 1978. Organizational learning: a theory of action perspective. Addison-Wesley, Reading, Mass. 344 p.

AMEND, D.A. 1989. Alaska's regional aquaculture associations: co-management of salmon in southern southeast Alaska, p. 125 134. In E. PINKERTON [ed.] Co-operative management of local fisheries. New directions for improved management and community development. University of British Columbia Press, Vancouver, B.C.

BEFU, H. 1980. Political ecology of fishing in Japan: techno-environmental impact of industrialization in the Inland Sea. Res. Econ. Anthropol. 3: $323-347$.

BERKES, F. 1981. The role of self-regulation in living resource management in the north, p.166-177. In M.M.R. FREEMAN [ed.] Renewable resources and the economy of the north. ACUNS/MAB, Ottawa, Ont.

Berkes, F., R. Preston, And P. George. 1991. The evolution in theory and practice of the joint administration of living resources. Alternatives 18: $12-18$.

Bisson, P.A., T.P. QuinN, G.H Reeves, And S.V. Gregory. 1992. Best management practices, cumulative effects, and long-tern trends in fish abundance in Pacific Northwest river systems, p. 189-232. In R.J. NaIMAN [ed.] Watershed management. Balancing sustainability and environmental change. Springer-Verlag, New York, N.Y.

BLOMQUIST, W. 1992. Dividing the waters: governing groundwater in southern California. ICS Press, San Francisco, Calif. 409 p.

Bowles, F., AND M. Bowles. 1989. Holding the line: property rights in the lobster and herring fisheries of Matinicus Island, Maine, p. 228-257. In J. CORDELL [ed.] A sea of small boats. Cultural Survival Inc., Cambridge, Mass.

BROMLEY, D. 1989. Economic interests and institutions: the conceptual foundations of public policy. Basil Blackwell, New York, N.Y. 274 p.

BRown, L.D. 1991. Bridging organizations and sustainable development. Hum. Rel. 44: 807-831.

BRown, D. 1993. A critical look at DFO's reforms. Fisherman 58: 14

BRuUN, R. 1982. The Boldt decision: legal victory, political defeat. Law Pol. Q. 4: $271-298$.

CARRIER, J., AND A. CARRIER. 1989. Marine tenure and economic reward on Ponam Island, Manus Province, p. 94-120. In John Cordell [ed.] A sea of small boats. Cultural Survival, Inc, Cambridge, Mass.

Ciriacy-Wanthrup, S.V., and R.C. Bishop. 1975. "Common property" as a concept in natural resource policy. Nat. Resour. J. 15: 713-727.

COHEN, F. 1986. Treaties on trial. The continuing controversy over northwest indian fishing rights. With contributions by Joan La France and Vivian Bowden. University of Washington Press, Seattle, Wash. 229 p.

Commitin, S. 1966. Marine resource exploitation and management in the economic development of Japan. Econ. Dev. Cult. Change. 14: 414-427.

Common Ground Project. 1993. The Common Ground Project prospectus and annexes. Fisheries Centre, University of British Columbia, Vancouver, B.C. 9 p.

Cruickshank, D. 1991. A commission of inquiry into licencing and related policies of the Department of Fisheries and Oceans. T.D. Mock, Victoria, B.C. 113 p.

DALE, N. 1989. Getting to co-management: social learning in the redesign of fisheries management, p. 49-72. In E. PINKERTON [ed.] Co-operative management of local fisheries: new directions for improved management and community development. University of British Columbia Press, Vancouver, B.C.

DEPARTMENT OF Fisheries AND OCEANS (DFO). 1988. Pacific region salmon stock management plan. I Inner south coast and Fraser River. Discussion Document 1986. Department of Fisheries and Oceans, 555 West Hastings, Vancouver, B.C. V6B 5G2. 204 p.

Department of Fisheries and OCEANS (DFO). 1991. Report on the Central Coast salmon stock management plan (SSMP) process. Program Planning and Economics Branch, Pacific Region, Department of Fisheries and Oceans, 555 West Hastings, Vancouver, B.C. V6B 5G2. 36 p.

DEPARTMENT OF Fisheries AND OCEANS (DFO). 1993a. Salmon expectations. Central coast. Pacific Region, Department of Fisheries and Oceans, 555 West Hastings, Vancouver, B.C. V6B 5G2. 191 p.

Department of Fisheries and OCEans (DFO). 1993b. West Coast Fisheries, changing times. Aboriginal Fisheries. Department of Fisheries and Oceans, Stations 314, 555 West Hastings St., Vancouver, BC V6B 5G3

DobYNs, D. 1992. Watershed negotiations in the Nooksack River basin: a co-operative evaluation with a tribal perspective. M.S. thesis, Western Washington University, Bellingham, Wash. $60 \mathrm{p}$.

DYer, C.L., AND J.R. MCGoodwin [ed.], 1994. Folk management in the world's fisheries: lessons for modern fisheries management. University Press of Colorado, Niwot, Colo. 347 p.

Feeny, D., F. Berkes, B. MCCAY, AND J. ACHESON. 1990. The tragedy of the commons: twenty-two years later. Hum. Ecol. 18: 1-19.

FRASER, G.A. 1979. Limited entry: experience of the British Columbia salmon fishery. J. Fish. Res. Board Can. 36: 754-763.

Gilhousen, P. 1990. Prespawning mortalities of sockeye salmon in the Fraser River system and possible causal factors. Bull. 26: International Pacific Salmon Fisheries Commission. Vancouver, B.C. 58 p.

GRAY, B. 1985. Conditions facilitating interorganizational collaboration. Hum. Rel. 38: 911-936.

GraY, B. 1991. Collaborating: finding common ground for multi-party problems. Jossey-Bass, San Francisco, Calif. 329 p.

GREER, A. 1993. Local salmon management. A proposal for co-operative, community-based management of Canada's Pacific salmon resource. Department of Fisheries and Oceans, 555 West Hastings, Vancouver, B.C. V6B 5G3. 25 p.

Groot, C., K. Denman, K. Hyatt, G. Jamieson, and D. Ware. 1992. Global climate change: British Columbia fisheries in a changing environment. Pacific Biological Station, Nanaimo, B.C. 12 p.

HARDin, G. 1968 . The tragedy of the commons. Science (Wash., D.C.) 162: $1243-1248$

HAYWARD, B. 1981. The B.C. salmon fishery: a consideration of the effects of licensing. B.C. Stud. 50: 39-51.

Henderson, M.A., D.A. Levy, and J.S. Stockner. 1992. Probable consequences of climate change on freshwater production of Adams River sockeye salmon. GeoJournal. 28: 51-59.

INTERNATIONAL DEVElopMENT RESEARCh CeNTRE (IDRC). 1991. Tomorrow's catch. IDRC Reports. 19: $27 \mathrm{p}$

IWAKIRI, S. 1983. Mataquali of the sea-a study of the customary right on reef and lagoon in Fiji, the South Pacific. Mem. Kagoshima Univ. Res. Cent. South Pac. 4: 133-143.

JeNTOFT, S., AND T. KRISTOFFERSEN. 1989. Fishermen's co-management: the case of the Lofoten fishery. Hum. Organ. 48: 355-365.

JoHANNES, R.E. 1978. Traditional marine conservation methods in Oceania and their demise. Annu. Rev. Ecol. Syst. 9: 349-364.

JoHANNES, R.E. 1981. Words of the lagoon. University of California Press, Berkeley, Calif. 245 p.

JOHANNES, R.E. 1988. Research on traditional tropical fisheries: some implications for Torres Strait and Australian aboriginal fisheries, p. 30-41. In F. GRAY AND L. ZANN [eds.] Traditional knowledge of the marine environment in northern Australia. Great Barrier Reef Marine Park Authority, Townsville, Australia.

KALlAND, A. 1981. Shingu. A study of a Japanese fishing community. Scand. Inst. Asian Stud. Monogr. Ser. 44: 198 p.

KEARNEY, J.F. 1983. Common tragedies: a study of resource access in the Bay of Fundy herring fisheries. M.A. thesis, Dalhousie University, Halifax, N.S. 441 p.

KLEE, G.A. [ed.]. 1980. World systems of traditional resource management. John Wiley \& Sons, New York, N.Y. 290 p.

KNAPP, G. 1992. Alaska salmon markets and prices. Institute of Social and Economic Research, University of Alaska, Anchorage, Alaska. $50 \mathrm{p}$.

KofINAS, G., AND J. GRIGGS. 1993. Collaboration and the B.C. Round Table: an early-stage analysis of a "better way" of deciding. In T. GUNTON AND M. ROSELAND, [eds.] Alternative dispute resolution and public land planning: the Canadian experience. (Unpublished manuscript, available from 2208 Cyress St., Vancouver, V6J 3M5.) 53 p.

Kravanja, M. 1992. Russia-Japan hatchery projects. National Marine Fisheries Service, Silver Springs, Md. 12 p.

LARKIN, P. 1991. The wet revolution. Fisheries production to the year 2025. Address to the American Fisheries Society Workshop, May 1991, 21-23. Snowbird, Utah. University of British Columbia, 2204 Main Mall, Vancouver, B.C. $35 \mathrm{p}$

LAwSON, P. 1993. Cycles in ocean productivity, trends in habitat quality and restoration of salmon runs in Oregon. Fisheries. (Bethesda) 188: 6-10.

LeE, R., AND I. DEVoRe [ed.]. 1968. Man the hunter. Aldine, Chicago, Ill. $415 \mathrm{p}$.

LEVIEIL, D.P. AND B. ORLOVE. 1990. Local control of aquatic resources: community and ecology in Lake Titicaca, Peru. Am. Anthropol. 92: 362-382. 
LEVY, D.A. 1992. Potential impacts of global warming on salmon production in the Fraser River watershed. Fraser River Environmentally Sustainable Task Force. Can. Tech. Rep. Fish. Aquat. Sci. 1889. 96 p.

Lichatowich, J. 1994. Components of management baselines. Paper presented at "Pacific Salmon and their Ecosystems", Seattle, WA. 117-C Don Schmith, Sequim, WA 98382.32 p.

MarchaK, P.M., N. GUPPY AND J. MCMULlin [ed.]. 1987. Uncommon property. The fishing and fish processing industries in British Columbia. University of British Columbia Press, Vancouver, B.C. 402 p.

Martin, F. 1989. Common pool resources and collective action: a bibliography. Vol. 1. Workshop in Political Theory and Policy Analysis, Indiana University, Bloomington, Ind. $310 \mathrm{p}$.

Martin, F. 1992. Common pool resources and collective action: a bibliography. Vol. 2. Workshop in Political Theory and Policy Analysis, Indiana University. Bloomington, Ind. $140 \mathrm{p}$.

MCCAY, B.J. 1989. Sea tenure and the culture of the commoners, p. 203-227. In J. CORDELl [ed.] A sea of small boats. Cultural Survival, Inc., Cambridge, Mass.

MCCAY, B.J. AND J. ACHESON [ed.]. 1987. The question of the commons: the culture and ecology of communal resources. University of Arizona Press, Tucson, Ariz. 439 p.

McEvoY, A.F. 1986. The fisherman's problem: ecology and law in the California fisheries, 1850-1980. Cambridge University Press, New York, N.Y. 368 p.

McGoodwin, J.R. 1990. Crisis in the World's Fisheries: People, Problems, and Policies. Stanford University Press, Stanford, Calif. 235 p.

Nehlsen, W., J.E. Williams, and J.A. Lichatowich. 1991. Pacific salmon at the crossroads: stocks at risk from California, Oregon, Idaho, and Washington. Fisheries (Bethesda) 16: 4-21.

NetBoy, A. 1968. The atlantic salmon. A vanishing species? Houghton Mifflin, Boston, Mass. 457 p.

NetBoy, A. 1973. The salmon. Their fight for survival. Houghton Mifflin, Boston, Mass. $613 \mathrm{p}$

NetTING, R. 1976. What alpine peasants have in common: observations on communal tenure in a Swiss village. Hum. Ecol. 4: 135-146.

NoRthcote, T.G., AND D.Y. ATAGi. 1994. Pacific salmon abundance trends in the Fraser River watershed compared with other British Columbia systems. Paper read at the conference Pacific Salmon and Their Ecosystems. Jan. 10-12, 1994, Seattle, Wash. Department of Fisheries and Oceans, 610 Derwent Way, Annacis Island, New Westminster, B.C. V3M 5P8. $26 \mathrm{p}$.

OSBORNE, D., AND T. GAEBLER. 1992. Reinventing government: how the entrepreneurial spirit is transforming the public sector. AddisonWesley, New York, N.Y. 405 p.

Ostrom, E. 1987. Institutional arrangements for resolving the commons dilemma: some contending approaches, p. 250-265. In B. MCCAY AND J. ACHESON [ed.] The question of the commons: the culture and ecology of communal resources. University of Arizona Press, Tucson, Ariz.

Ostrom, E. 1990. Governing the commons. The evolution of institutions for collective action. Cambridge University Press, Cambridge, UK. 280 p.

PAvel, J. 1989. The Puget Sound salmon management plan: a co-operative management tool, p. 22-29. In B.L. SMITH AND P. HURT [ed.] Fisheries co-management: a response to legal, social and fiscal imperatives. Great Lakes Indian Fish and Wildlife Commission, Odanah, Wis.

PeArse, P. 1982. Turning the tide. A new policy for Canada's Pacific fisheries. Final Report. The Commission on Pacific Fisheries Policy, Department of Fisheries and Oceans, 555 West Hastings, Vancouver, B.C. V6B 5G3. 292 p.

Pinkerton, E.W. 1988. Co-operative management of local fisheries: a route to development, p. 257-273. In J.W. BENNETT AND J.R. BOWEN [ed.] Production and autonomy. Anthropological studies and critiques of development. Monogr. Econ. Anthropol. 5.

PinKerTon, E.W. 1989. Introduction. Attaining better fisheries management through co-management-prospects, problems, and propositions. In E.W. PINKERTON [ed.] Cooperative management of local fisheries: new directions for improved management and community development. University of British Columbia Press, Vancouver, B.C.

Pinkerton, E.W. 1991. Locally based water quality planning: contributions to fish habitat protection. Can. J. Fish. Aquat. Sci. 48: 1326-1333.

PINKERTON, E.W. 1992. Translating legal rights into management practice: overcoming barriers to the exercise of co-management. Hum. Organ. 51: $330-341$.

PinkerTON, E.W. 1994a. Summary and conclusions, p. 317-337. In C.L. DYER AND J.R. MCGOODWIN [ed.] Folk management in the world's fisheries. University Press of Colorado, Niwot, Colo.
Pinkerton, E.W. 1994b. Economic and management benefits from the co-ordination of capture and culture fisheries: the case of Prince William Sound pink salmon. N. Am. J. Fish. Manage. 14: 262-277.

Pinkerton, E.W., and N. Kertlah. 1990. The Point No Point Treaty Council: innovations by an inter-tribal fisheries management cooperative. School of Community and Regional Planning and Nuu-chah-nulth Tribal Council, UBC Centre for Human Settlements, 2206 East Mall, Vancouver, B.C. V6T IW5. 54 p.

Pinkerton, E.W. AND S. LANGDON. 1987. Regional aquaculture associations in Alaska: an overview, p. 1-23. In E. Pinkerton, F. COHEN, S. LANGdon, N. Keitlah, W. ReEs, P. Boothroyd, D. Lightly, and B. GREEN [ed.] Launching a fisheries co-management pilot project: learning from the experience of Alaska and Washington State. Phase I. Final Report. Department of Fisheries and Oceans, Indian and Northern Affairs, B.C. Native Affairs Secretariat. 555 West Hastings, Vancouver, B.C. V6B 5G3. 23 p.

Pinkerton, E.W., D. Moore, And F. Fortier. 1993. A model for First Nation leadership in multi-party stewardship of watersheds and their fisheries. Report to the Royal Commission on Aboriginal Peoples. Ottawa, Ont. 26 p.

PITT, D. 1993. The overfishing crisis: there's ample cause for global alarm. Vancouver Sun, Vancouver, B.C. August 7: B4

Public POLICY Forum. 1993. Making government work. 130 Albert St. Ottawa, ON K1P 5G4. 23 p.

ReICH, R. 1988. Policy-making in a democracy, p. 123-156. In R. Reich, [ed.] The power of public ideas. Ballinger, Cambridge, Mass.

RIDDELL, B. 1993. Spatial organization of Pacific salmon: what to conserve? p. 23-41. In J. G. Cloud and G. H. ThORGaARd [ed.] Genetic conservation of salmonid fishes. NATO ASI Ser. A.

RUDDLE, K. 1989. Solving the common property dilemma: village fisheries rights in Japanese coastal waters, p. 168-184. In F. BERKES, [ed.] Common property resources. Ecology and community-based sustainable development. Belhaven Press, London.

RuddLE, K., AND T. AKIMICHI [ed.]. 1984. Maritime institutions in the western pacific. National Museum of Ethnology, Osaka, Japan. $329 \mathrm{p}$.

RudDle, K., AND R.E. JohanNEs [ed.] 1985. The traditional knowledge and management of coastal systems in Asia and the Pacific. UNESCO, Jakarta Pusat, Indonesia. 313 p.

Seiler, D., P. Hanratty, S. Neuhauser, P. Topping, M. Ackley, And L. KISHIMOTO. 1992. Wild salmonid production and survival evaluation. Washington Department of Fisheries, P.O. Box 43138, Olympia, WA $98504-2700.40 \mathrm{p}$.

SEITER, A.E. 1993. Putting process into practice: tribal leadership in regional water planning. Paper for the American Water Resource Association Symposium. 27-30 June 1993. Seattle, Wash. Jamestown S'Klallam Tribe, 1103 Old Blyn Highway, Sequim, WA 98382. 12 p.

SHORT, K. 1989. Self-management of fishing rights by Japanese co-operative associations: a case study from Hokkaido, p. 371-387. In J. CORDELL [ed.] A sea of small boats. Cultural Survival, Inc., Cambridge, Mass.

SMiTH, C. 1994. Connecting cultural and biological diversity in restoring northwest salmon. Fisheries (Bethesda) 19: 20-26

Stoffle, B.W., D.B. Halmo, R.W. Stoffle, and G.G. Burpee. 1994. Folk management and conservation ethics among small-scale fishermen of Buen Hombre, Dominican Republic, p. 115-138. In C.L. DYER AND J.R. MCGoodwin [ed.] Folk management in the world's fisheries. University Press of Colorado, Niwot, Colo.

TAYLOR, G. 1993. Proposal for a new salmon management regime on the Skeena River. M.A. thesis. Simon Fraser University. Burnaby, B.C. $75 \mathrm{p}$.

WALTERS, C.J. 1988. Mixed-stock fisheries and the sustainability of enhancement production for chinook and coho salmon, p. 109-115. In W.J. MCNEIL [ed.] Salmon production, management, and allocation: biological, economic, and policy issues. Oregon State University Press. Corvallis, Oreg.

WALTERS, C.J., R.D. GoRuK AND D. RADFORD. 1993. Rivers Inlet sockeye salmon: an experiment in adaptive management. N. Am. J. Fish. Manage. 13: 253-262

WIGEN, K. 1989. Shifting control in Japan's coastal waters, p. 388-410. In J. Cordell [ed.] A sea of small boats. Cultural Survival, Inc., Cambridge, Mass.

WithleR, F.C. 1982. Transplanting Pacific salmon. Can. Tech. Rep. Fish. Aquat. Sci. 1079: 27 p. 